\title{
Potential of Exopolysaccharide from Porphyridium marinum to Contend with Bacterial Proliferation, Biofilm Formation, and Breast Cancer
}

\author{
Nesrine Gargouch ${ }^{1,2}$, Fatma Elleuch ${ }^{3,4}$, Ines Karkouch ${ }^{5}$, Olfa Tabbene ${ }^{5}$, Chantal Pichon ${ }^{3}$, Christine Gardarin ${ }^{1}$, \\ Christophe Rihouey ${ }^{6}$, Luc Picton ${ }^{6}$, Slim Abdelkafi ${ }^{4}$, Imen Fendri ${ }^{2}$ and Céline Laroche ${ }^{1, *}$ \\ 1 Institut Pascal, CNRS, SIGMA Clermont, Université Clermont Auvergne, F-63000 Clermont-Ferrand, France; \\ nesrinekarkouch@hotmail.fr (N.G.); christine.gardarin@uca.fr (C.G.) \\ 2 Laboratoire de Biotechnologie Végétale Appliquée à l'Amélioration des Cultures, Faculty of Sciences of Sfax, \\ University of Sfax, Sfax 3000, Tunisia; imenfendri@fss.usf.tn \\ 3 Centre de Biophysique Moléculaire, CNRS-UPR 4301, 45071 Orléans, France; fatmaelleuch@ymail.com (F.E.); \\ chantalpichon@cnrs-orleans.fr (C.P.) \\ 4 Unité de Biotechnologie des Algues, Biological Engineering Department, National School of Engineers of \\ Sfax, University of Sfax, Sfax 3038, Tunisia; slimabdelkafi@enis.tn \\ 5 Laboratory of Bioactive Substances, Biotechnology Center of Borj-Cedria (CBBC), BP-901, \\ Hammam-Lif 2050, Tunisia; karkouch_ines@yahoo.fr (I.K.); olfa.tabbene@cbbc.rnrt.tn (O.T.) \\ 6 Normandie University, UNIROUEN, INSA Rouen, CNRS, PBS, 76000 Rouen, France; \\ christophe.rihouey@univ-rouen.fr (C.R.); luc.picton@univ-rouen.fr (L.P.) \\ check for \\ * Correspondence: celine.laroche@uca.fr; Tel.: +33-473-40-74-19
} updates

Citation: Gargouch, N.; Elleuch, F.; Karkouch, I.; Tabbene, O.; Pichon, C.; Gardarin, C.; Rihouey, C.; Picton, L.; Abdelkafi, S.; Fendri, I.; et al.

Potential of Exopolysaccharide from Porphyridium marinum to Contend with Bacterial Proliferation, Biofilm Formation, and Breast Cancer. Mar. Drugs 2021, 19, 66. https://doi.org/ 10.3390/md19020066

Academic Editors: Irina M. Yermak and Viktoria Davydova

Received: 23 December 2020

Accepted: 22 January 2021

Published: 27 January 2021

Publisher's Note: MDPI stays neutral with regard to jurisdictional claims in published maps and institutional affiliations.

Copyright: (c) 2021 by the authors. Licensee MDPI, Basel, Switzerland. This article is an open access article distributed under the terms and conditions of the Creative Commons Attribution (CC BY) license (https:// creativecommons.org/licenses/by/ $4.0 /)$.

\begin{abstract}
Exopolysaccharide (EPS) from marine microalgae are promising sources of a new generation of drugs. However, lot of them remain to be discovered and tested. In this study, EPS produced by Porphyridium marinum and its oligomers prepared by High Pressure Homogenizer have been tested for different biological activities, i.e., antibacterial, anti-fungal and antibiofilm activities on Candida albicans, as well as for their effects on the viability of murine breast cancer cells. Results have shown that all EPS samples present some biological activity. For antibacterial and antibiofilm activities, the native EPS exhibited a better efficiency with Minimum Inhibitory Concentration (MIC) from $62.5 \mu \mathrm{g} / \mathrm{mL}$ to $1000 \mu \mathrm{g} / \mathrm{mL}$ depending on the bacterial strain. For Candida albicans, the biofilm formation was reduced by about $90 \%$ by using only a $31.3 \mu \mathrm{g} / \mathrm{mL}$ concentration. Concerning breast cancer cells, lower molar masses fractions appeared to be more efficient, with a reduction of viability of up to $55 \%$. Finally, analyses of polymers composition and viscosity measurements were conducted on all samples, in order to propose hypotheses involving the activities caused by the intrinsic properties of polymers.
\end{abstract}

Keywords: Porphyridium marinum; exopolysaccharide; high pressure homogenizer; antibacterial activity; anti-biofilm activity; anti-cancer activity

\section{Introduction}

In recent years, several studies have been conducted on bioactive molecules extracted from microalgal strains such as carbohydrate polymers, proteins, lipids and pigments whose biological and physicochemical properties can be used in the food, cosmetics, medical and pharmacological industries [1,2]. Among these microalgae, red microalgae, especially the genus Porphyridium and Rhodella, have attracted interest for their richness in sulfated exopolysaccharides (EPS). The molar masses of EPS in these genera is in a range of 2-7 $\times 10^{6} \mathrm{Da}$ [3]. These anionic sulfated PS contain glucuronic acid and several major neutral sugars such as xylose, galactose and glucose [3,4]. Nevertheless, the structures of these exopolymers have not yet been elucidated except for some oligosaccharidic sequences [5]. These polymers have many potential activities, including antiviral, anti-tumor 
and antioxidant activities. All of these activities were reported to be linked to these polymers' physicochemical characteristics such as the degree of sulfation, molecular weight and their rheological behavior [2,4]. However, studies on their antibacterial, anti-fungal and antibiofilm activities remain scarce.

The red microalga Porphyridium marinum was studied only for its production of exopolysaccharides and the antiparasitic activity these exopolysaccharides cause for honey bee infection through microsporidia Nosema ceranae [6,7]. In this study, EPS produced by $P$. marinum and its oligomers prepared by High Pressure Homogenizer (HPH) were evaluated for several biological activities. These activities were (i) their ability to inhibit the multiplication of Gram (+) and (-) bacterial strains, (ii) the multiplication and biofilm formation of Candida albicans yeast and (iii) the proliferation of breast cancer cells. The HPH technique consists of continuously forcing a liquid flow at low velocity using a volumetric pump through a restriction between a seat and a valve, the size of which can be imposed in order to control pressure drop. This technique is a green and non-thermal technology, unlike the most widely used namely chemical and thermal (microwave) methods that are limited by their efficiencies and their toxicities by using chemicals products such as trifluoroacetic acid and sulfuric acid. Moreover, $\mathrm{HPH}$ is less costly than enzymatic methods which are simple but often limited by the commercial availability of enzymes, their cost and their sensitivity to denaturation. Furthermore, it is a versatile tool that is commonly used in food and pharmaceutical industries for making emulsions, solid dispersions or cell lyses [8]. Finally, analyses of polymers composition and viscosity measurements were conducted on all EPS fractions, in order to match the activities with the intrinsic properties of polymers and to propose hypotheses on the action mechanism.

\section{Results}

\subsection{Production of Different Molar Masses Exopolysaccharides by HPH}

High Pressure Homogenization, which has been shown to be effective in reducing the molar masses of polysaccharides $[9,10]$, has been applied to EPS produced by the red microalga P. marinum in order to obtain lower molar masses exopolysaccharides and therefore to decrease their viscosity. EPS obtained from P. marinum were submitted to up to five cycles of $\mathrm{HPH}$ at a pressure of $2.7 \mathrm{kbar}$ and three exopolysaccharide fractions were recovered, such as untreated EPS (EPS-0C), EPS after two HPH passes (EPS-2C) and EPS after five HPH passes (EPS-5C).

The number and weight average molar masses (respectively $\mathrm{Mn}$ and $\mathrm{Mw}$ ), gyration

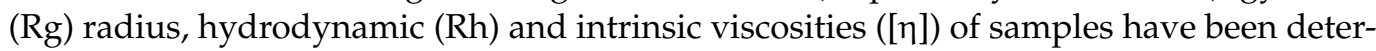
mined by Steric Exclusion Chromatography coupled to multi-angle laser light scattering, viscometry and a differential refractive index (SEC/MALLS/Visco/DRI) and are reported in Table 1.

Table 1. Macromolecular characterization of P. marinum EPS samples.

\begin{tabular}{ccccccc}
\hline Samples & \% Recovery & $\mathbf{M}_{\mathbf{n}} \mathbf{( k D a )}$ & $\mathbf{M}_{\mathbf{w}} \mathbf{( k D a )}$ & $\mathbf{R g}(\mathbf{n m})$ & $\mathbf{R h}(\mathbf{n m})$ & {$[\mathbf{\eta}] \mathbf{m L} / \mathbf{g}$} \\
\hline EPS-0C & 8.5 & $890( \pm 35 \%)$ & $1400( \pm 40 \%)$ & $150( \pm 5 \%)$ & $67( \pm 5.1)$ & $1480( \pm 1 \%)$ \\
EPS-2C & 73 & $400( \pm 0.7 \%)$ & $550( \pm 2 \%)$ & $43( \pm 2 \%)$ & $26( \pm 0.5)$ & $230( \pm 0.4 \%)$ \\
EPS-5C & 72 & $340( \pm 0.6 \%)$ & $550( \pm 4 \%)$ & $41( \pm 3 \%)$ & $21( \pm 0.6)$ & $155( \pm 0.5 \%)$ \\
\hline
\end{tabular}

$\mathrm{M}_{\mathrm{w}}$ : Weight-average molar mass estimated by SEC-MALLS-DRI. $\mathrm{M}_{\mathrm{n}}$ : Number-average molar mass estimated by SEC MALLS-DRI.

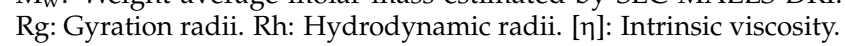

$\mathrm{M}_{\mathrm{w}}$ and $\mathrm{M}_{\mathrm{n}}$ of the native exopolysaccharides were about 1400 and $900 \mathrm{kDa}$, respectively. Nevertheless, due to an important retention of exopolysaccharide during the filtration (on a $0.45 \mu \mathrm{m}$ filter), these value are characteristic of less than $10 \%$ (Table 1) of the initial mass of the sample before filtration. This low amount of analyzed sample is indicative of the large level of uncertainty on the molar mass determination. However, these values of molar masses seem to be congruent with the results previously reported by Soanen et al. [7] for EPS from P. marinum (1800 kDa, recovery rate of 30\%). This large loss 
could be explained by the presence of very large aggregated structures, as we observed high values of hydrodynamic and gyration radii (67 and $150 \mathrm{~nm}$, respectively), but also by the fact that the elution was disperse (i.e., elution on a large volume, thus corresponding to variations in $\mathrm{Rg}$ and $\mathrm{Rh}$, but with a quite constant molar mass). Such comportment has also been observed by other authors while analyzing molar masses for microalgae EPS. The work of [11] on Porphyridium sp. EPS could be cited in this context, who also suggested the presence of aggregates, as well as a more recent study on Porphyridium cruentum [12]. Such large aggregates can be the consequence of hydrophobic associations (the presence of esterified sugar or amphiphilic proteins), hydrogen bonds or complexes between polysaccharides and/or proteins. Besides, we have demonstrated in a previous study on Flintiella sanguinaria EPS [13] that large aggregates were present. Conformation analysis in dilute solution with a chaotropic salt (KSCN) led to a partial disaggregation of it, suggesting intermolecular interactions by hydrogen or hydrophobic interactions due to the presence of methyl and acetyl groups on the polysaccharide backbone. However, a protease treatment also confirmed that proteins significantly contribute to this associative structure, but mainly by intramolecular interactions. Thus, even if we have not explored this interaction mechanism more in depth in the present study, the presence of such large aggregates is very likely. In contrast to EPS-0C, the filtration losses of the EPS fractions obtained after two or five passes in the HPH are considerably reduced (about $70 \%$ of the samples have been analyzed, see Table 1), leading to more significant values of the polymer physicochemical characteristics. This can be attributed to the decrease in molar masses, even if some smaller aggregates can still remain. As expected, the molar masses of the treated EPS were substantially reduced from 1400 to $550 \mathrm{kDa}$ for $\mathrm{M}_{\mathrm{w}}$ together with the size (Rh from 67 to $21 \mathrm{~nm}, \mathrm{Rg}$ from 150 to $41 \mathrm{~nm}$ ) and [ $\eta$ ] from about 1500 to $150 \mathrm{~mL} / \mathrm{g}$ ). Therefore, the HPH treatment was clearly effective to reduce both molar masses, hydrodynamic and gyration radius of polymers by a factor of 2.5, 3 and 3.5, respectively. However, the difference between the 2 nd and 5 th passage appears to not be really significant.

\subsection{Structural and Physico-Chemical Characterization of EPS Samples}

The purity of the native EPS (EPS-0C) was first evaluated, showing that our sample was constituted of $62 \%$ sugars. Additionally, $9 \% \pm 0.04$ of proteins were found to be present in the polysaccharide extract. This percentage is consistent with those generally found in the literature for EPS from red microalgae [2]. Some authors have even suggested that these proteins could be covalently bound to the polysaccharidic moiety [14]. No further purification was then applied to the sample.

Biological activity of polysaccharides is often attributed to the presence of sulfate groups and uronic acids in their structure. The composition of the 3 samples was analyzed by colorimetric assays, HPAEC-PAD and FTIR. As shown in Table 2, no modification of the global composition was noticed since all samples were composed of around $22 \%$ of uronic acids, and $9 \%$ of sulfate groups. The HPAEC chromatograms are provided as Supplementary Materials.

Concerning monosaccharides composition, the exopolysaccharides of P. marinum consisted mainly of xylose, galactose and glucose as previously reported by Soanen et al. [7]. Only slight differences were noticed between treated and untreated samples, which were considered to not be significant. This result is in accordance with the fact that no additional purification step was included after HPH treatment, so all monosaccharides present in the native sample remained in the treated ones. Differences between uronic acids content obtained by colorimetric assay ( $22 \%$ in weight) and HPAEC ( $\sim 5 \%$ molar ratio glucuronic acid) could be attributed to the presence of an unidentified peak in HPAEC corresponding to another acidic monosaccharide. This hypothesis is supported by the fact that methylated glucuronic acid (2-O-Me-GlcA) has been described for Porphyridium cruentum [15], and more recently, [16] have observed the presence of a methylated uronic acid in the EPS from Porphyridium sordidum. Moreover, this peak has been already observed by authors while analyzing the EPS from Flintiella sanguinaria (another red marine microalgae). During 
this study, it was concluded that this peak should correspond to a methylated and/or acetylated glucuronic acid. This hypothesis was formulated because the analysis of the desubstituted sample (specific treatment to release methyl and acetyl groups for their quantification), led to the disappearance of this peak and increase in the area of glucuronic acid peak. However, the lack of commercial standards prevented its formal identification and quantification [13].

Table 2. Uronic acids, sulfate content and monosaccharide composition of the different polysaccharidic samples.

\begin{tabular}{cccc}
\hline & & EPS Samples & \\
\hline & EPS-0C & EPS-2C & EPS-5C \\
\hline Uronic acids (\%) & $22 \pm 0.1$ & $22 \pm 0.1$ & $21 \pm 0.2$ \\
Sulfates (\%) & $9.2 \pm 0.3$ & $8.7 \pm 0.8$ & $9.2 \pm 0.7$ \\
Xylose (\%) & 47 & 47 & 44 \\
Galactose (\%) & 25 & 25 & 29 \\
Glucose (\%) & 20 & 19 & 20 \\
Fucose (\%) & 1 & 1 & 1 \\
Arabinose (\%) & 2 & 2 & 4 \\
Glucuronic acid (\%) & 5 & 5 & 4
\end{tabular}

Uronic acids and sulfates content were determined by colorimetric assays and expressed as Eq.GlcA and Eq.SO respectively. Values are the average of at least 3 independent assays. Monosaccharide composition was obtained by HPAEC and results expressed as molar ratios.

Finally, infrared spectrum analysis indicated that the HPH-depolymerized products had the same footprint as the native exopolysaccharide (Figure 1).

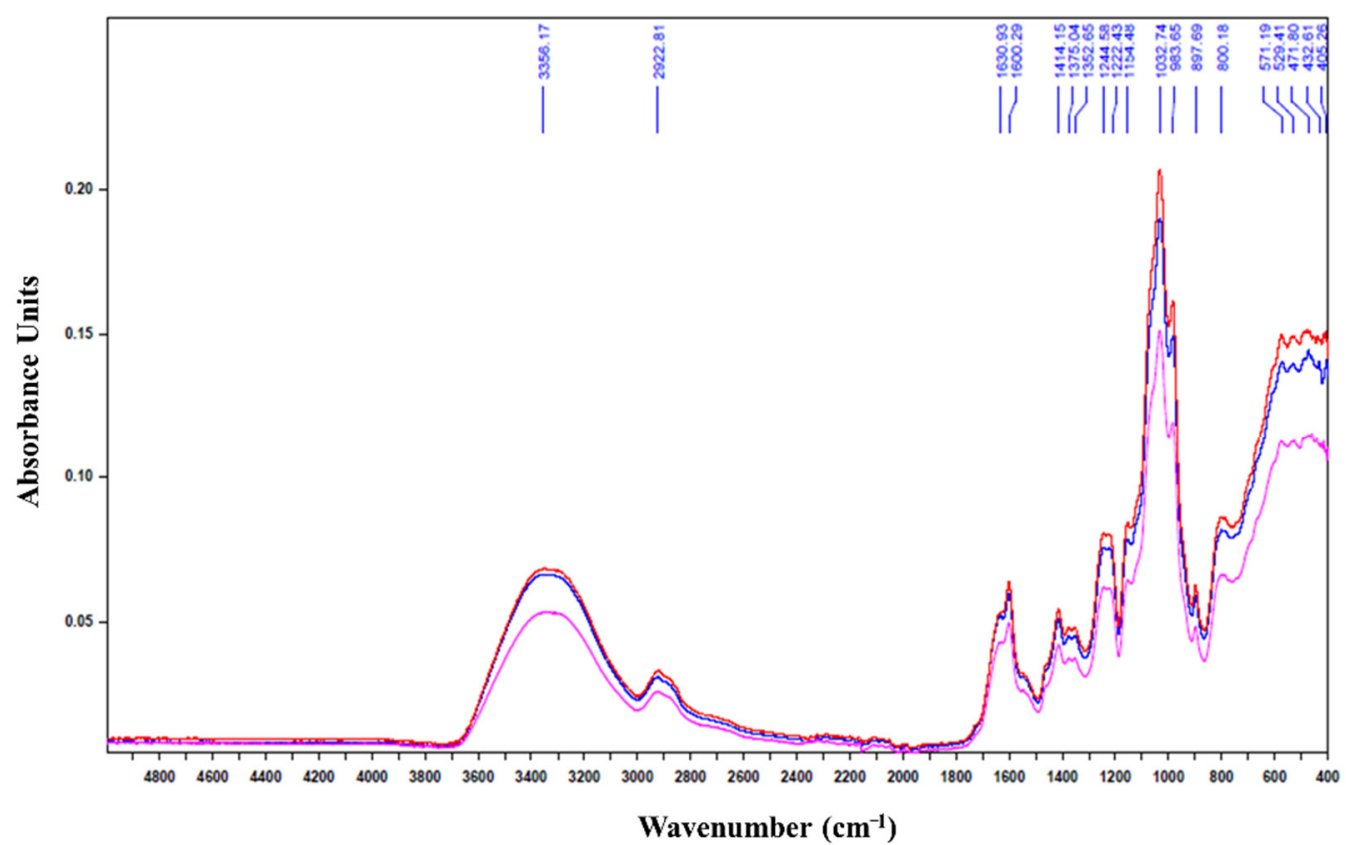

Figure 1. Infrared spectrum of exopolysaccharide (EPS) before and after passage in the high pressure homogenizer. Blue: EPS-0C, Red: EPS-2C, Pink: EPS-5C.

No difference was noticed in the absorption bands detected between 1630 and $1414 \mathrm{~cm}^{-1}$ which are characteristic of the asymmetric vibrations of the protonated and deprotonated carboxylic groups linked to the presence of uronic acids [17,18]. The $1222.43 \mathrm{~cm}^{-1}$ band characteristic of the $\mathrm{S}=\mathrm{O}$ sulfate groups [19] of the red microalgae EPS was retained for the two treated polysaccharides: EPS-2C and EPS-5C. Also, the absorption bands detected at $897.69 \mathrm{~cm}^{-1}$, characteristic of the deformation of the $\beta-C_{1}$ anomeric bonds [20,21], 
were well preserved during the depolymerization. The bands observed at $1154 \mathrm{~cm}^{-1}$ are characteristic of the glycosidic structure (C-O-C). In fact, the presence of these bands despite the depolymerization by HPH shows that only certain glycosidic bonds have been affected and altered. These results confirm the still high molar masses of EPS-2C and EPS-5C determined by SEC/MALLS (Table 1). These findings are consistent with those observed by [22] while extracting fucoidans from the seaweed Nemacystus decipients by several cycles of $\mathrm{HPH}$.

Apart from functional groups, the viscosity of polymers has been suggested to play a role in some biological activities. As an example, it has been demonstrated by Sun et al. [23] that by decreasing the average molar masses of the polymer, the viscosity was considerably reduced (in agreement with our results, see Table 1) and consequently the antioxidant activity gradually improved. Thus, the rheological behavior of the various exopolysaccharide extracts (EPS-0C, EPS-2C and EPS-5C) was explored in flow mode by plotting the viscosity curves as a function of the shear rate (Figure 2). The different samples were prepared at the same concentration $(1 \mathrm{mg} / \mathrm{mL})$ for a comparative study but also at some active concentrations that will be highlighted later in this paper $(125$ and $62.5 \mu \mathrm{g} / \mathrm{mL}$ for EPS-0C, 125 and $2500 \mu \mathrm{g} / \mathrm{mL}$ for EPS-2C as well as 250 and $2500 \mu \mathrm{g} / \mathrm{mL}$ for EPS-5C).

As shown in Figure 2A, the EPS-0C at the highest concentration, (i.e., $1000 \mu \mathrm{g} / \mathrm{mL}$ ) evidences a non-Newtonian and shear-thinning behavior that means the decrease of the viscosity of the solution with the increase of the shear rate. Moreover, the absence of a Newtonian plateau at low shear rates could be indicative of a yield stress behavior in agreement with a connected structure of the fluid. This result could be correlated to the high aggregation tendency showed in a diluted regime (SEC/MALLS/Visco/DRI measurements). Some papers described rheological behavior of microalgae EPS, including from Porphyridium species (P. cruentum [12], P. sordidum and P. purpureum [24]), but all were conducted at greater concentrations than in the present study $(0.125 \%$ or more), leading to difficulties in comparing viscosity values. However, they also observed a shear thinning behavior $[12,23,25,26]$. At lower concentrations (for $125 \mu \mathrm{g} / \mathrm{mL}$ and $62.5 \mu \mathrm{g} / \mathrm{mL}$ ), EPS-0C presents a quite Newtonian profile. Thus, the viscosity was found to be considerably decreased from $44.22 \mathrm{mPa}$.s $(1000 \mu \mathrm{g} / \mathrm{mL})$ to $2.95 \mathrm{mPa} . \mathrm{s}(125 \mu \mathrm{g} / \mathrm{mL})$ and $1.62 \mathrm{mPa} . \mathrm{s}(62.5 \mu \mathrm{g} / \mathrm{mL})$ at a shear rate of $10 \mathrm{~s}^{-1}$ (Figure 2A). This result is in agreement with Balti et al.'s [27] study, who observed a decrease in viscosity from 18.7 to $4.6 \mathrm{mPa}$.s when the sugar concentrations decreased from 1.74 to $0.48 \mathrm{~g} / \mathrm{L}$ at a shear rate equal to $15 \mathrm{~s}^{-1}$. On the other hand, the viscosities of EPS-2C and EPS-5C solutions have shown a linear relationship with the shear rate typical of Newtonian fluids (Figure 2B,C). Thus, decreasing the molar masses of EPS by HPH led to a significant impact on viscosity which decreased from $44.22 \mathrm{mPa}$.s for EPS-0C to $1.12 \mathrm{mPa}$.s (just slightly higher than water viscosity) for EPS-5C for a shear rate equal to $10 \mathrm{~s}^{-1}$. As for molar masses determination, no more effect between two and five passages has been detected with this rheological study. Partial depolymerization of EPS from Porphyridium sp. has been shown to strongly affect viscosity, with, for the lower molecular weight samples, a comportment typical of Newtonian fluids [23]. Villay et al. [8] showed the same effect on other types of polysaccharides (guar gum, hydroxyethylcellulose (HEC), sodium carboxymethylcellulose (Na-CMC), sodium alginate (Na-alginate) and gum Arabic) treated with $\mathrm{HPH}$. The effect of number of treatment cycles was similar for all the polysaccharides. The first treatment always had the strongest impact on viscosity reduction. Then, no effect on the zero-shear viscosity " $\eta_{\mathrm{s}}$ " was observed after 2 and 3 cycles. Finally, a slight decrease of $\eta_{\mathrm{s}}$ was observed between cycles 4 and 6 . At last, only a slight difference in viscosities of the treated samples could be detected as a function of concentration according to the expected dilute regime of concentration. These results were in accordance with the intrinsic viscosity $(\eta)$ measurements (Table 1 ) which decreased significantly after depolymerization from 1480 to $155 \mathrm{~mL} / \mathrm{g}$ (Table 1 ). 


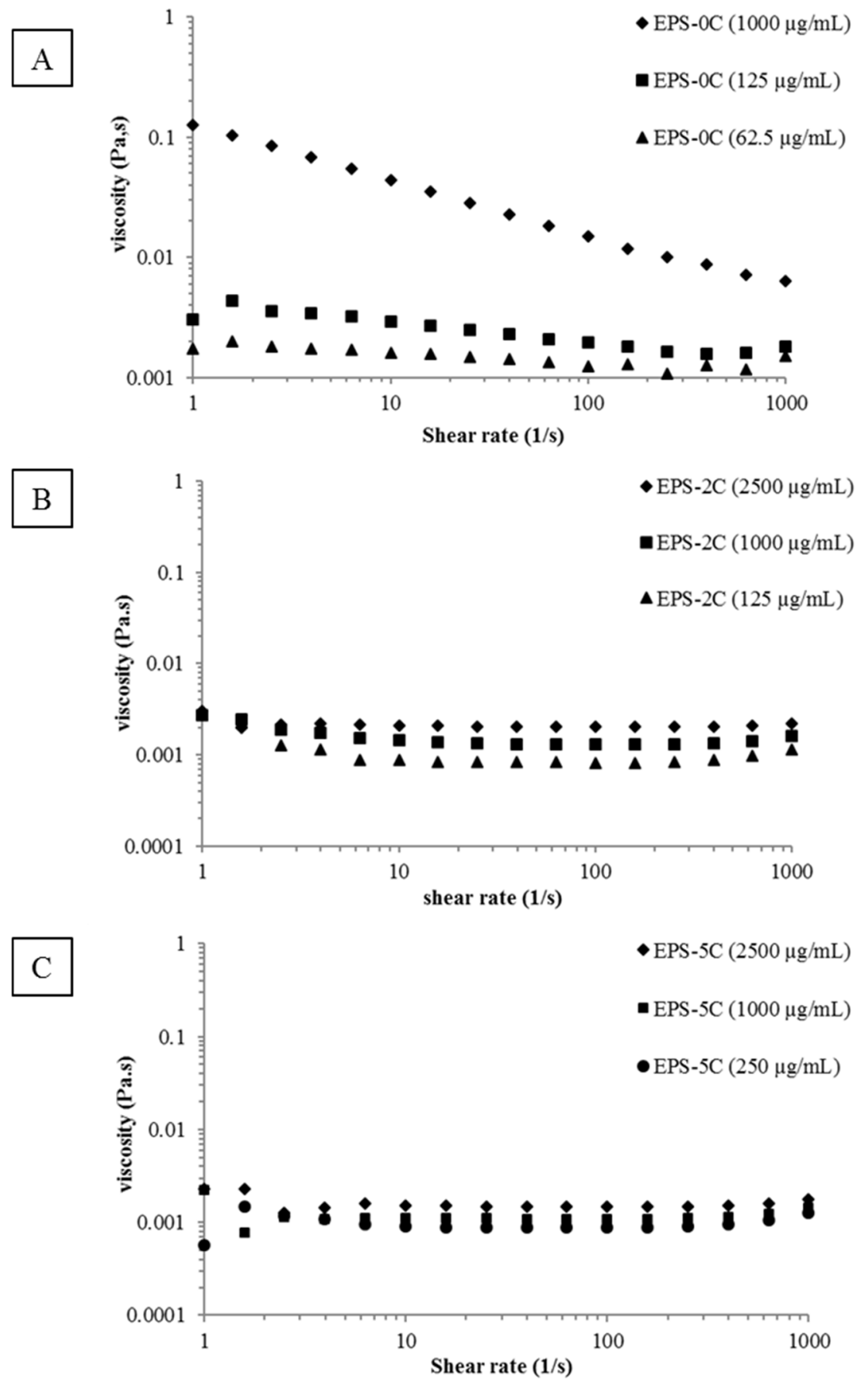

Figure 2. Shear flow behavior of EPS samples as a function of concentrations. (A): Native EPS (EPS-0C) at $1000 \mu \mathrm{g} / \mathrm{mL}(\boldsymbol{\vee}), 125 \mu \mathrm{g} / \mathrm{mL}(\boldsymbol{\square})$ and $62.5 \mu \mathrm{g} / \mathrm{mL}(\mathbf{\Delta}) ;(\mathbf{B})$ : EPS-2C at $2500 \mu \mathrm{g} / \mathrm{mL}(\boldsymbol{\vee}), 1000 \mu \mathrm{g} / \mathrm{mL}$

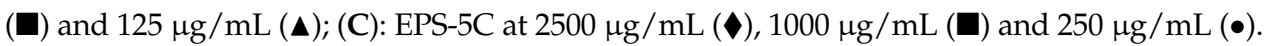

\subsection{Biological Activities}

2.3.1. Antibacterial and Anti-Candida Albicans Activities

The three EPS fractions were screened for their ability to inhibit the growth of four bacterial strains (Staphylococcus aureus ATCC 29213, methicillin resistant Staphylococcus aureus (SMR), Escherichia coli ATCC 25922 and Salmonella Enteritidis ATCC 13076) and the yeast Candida albicans ATCC 10231. 
All 3 EPS samples showed an antibacterial activity against the different bacterial strains tested. However, no antifungal activity against Candida albicans was detected. The most active was the native EPS that exhibited antibacterial activity against $E$. coli and Salmonella (Gram (-)) at MIC (Minimum Inhibitory Concentration) of $62.5 \mu \mathrm{g} / \mathrm{mL}$ and $125 \mu \mathrm{g} / \mathrm{mL}$, respectively. This extract has also shown growth inhibition of Gram $(+)$ bacteria at MIC $125 \mu \mathrm{g} / \mathrm{mL}$ for S. aureus and $1000 \mu \mathrm{g} / \mathrm{mL}$ for SMR. EPS-2C inhibited Gram (-) bacteria at a concentration of $2500 \mu \mathrm{g} / \mathrm{mL}$ and exhibited activity against S. aureus at a MIC of $1250 \mu \mathrm{g} / \mathrm{mL}$. Finally, EPS-5C showed an antibacterial activity against $E$. coli and S. aureus at a concentration of $2500 \mu \mathrm{g} / \mathrm{mL}$ (Table 3). The MIC value of the different EPS samples was higher than that of the reference antibiotics Cefazolin and Amphotericin B that were used as positive controls. Even if the antimicrobial potential of these conventional antimicrobial agents was higher than that of EPS, the later could represent a natural and safer molecule without secondary effects.

Table 3. Antibacterial and anti-Candida albicans activities of P. marinum EPS samples.

\begin{tabular}{|c|c|c|c|c|c|}
\hline \multirow{2}{*}{ Strains } & \multicolumn{5}{|c|}{ MIC ( $\mu \mathrm{g} / \mathrm{mL})$} \\
\hline & EPS-0C & EPS-2C & EPS-5C & Cefazolin & Amphotericin B \\
\hline \multicolumn{6}{|c|}{ Gram (-) Bacteria } \\
\hline Escherichia coli ATCC 25922 & 62.5 & 2500 & 2500 & 8 & - \\
\hline Salmonella Enteritidis & 125 & 2500 & - & 4 & - \\
\hline \multicolumn{6}{|c|}{ Gram (+) Bacteria } \\
\hline Staphylococcus aureus ATCC 29213 & 125 & 1250 & 2500 & 1 & - \\
\hline $\begin{array}{c}\text { Staphylococcus Methicilin } \\
\text { Resistant (SMR) }\end{array}$ & 1000 & - & - & 512 & - \\
\hline \multicolumn{6}{|c|}{ Yeast } \\
\hline Candida albicans ATCC 10231 & - & - & - & - & 0.125 \\
\hline
\end{tabular}

MIC: Minimal Inhibitory Concentration. (-): Not determined. Cefazolin and Amphotericin B were used as positive controls.

These antibacterial activities were also demonstrated by the appearance of an inhibition zone on agar medium using the well diffusion method at MIC concentrations obtained previously (Figure 3). According to this test, it clearly appeared that the various exopolysaccharide fractions have an inhibitory effect on the growth of the bacteria, manifested by the formation of an inhibition zone around the wells. This area depended on the sensitivity of the bacterial strain to the EPS extract and its concentration. Indeed, Escherichia coli ATCC 25922 was found to be the most sensitive Gram (-) bacterium to EPS-0C with a MIC of $62.5 \mu \mathrm{g} / \mathrm{mL}$ while Staphylococcus aureus ATCC 29213 was the most sensitive Gram (+) bacterium to EPS-0C with a MIC equal to $125 \mu \mathrm{g} / \mathrm{mL}$. This sensitivity was revealed by an inhibition zone which was the most extensive in comparison with those of the other polysaccharide extracts (Figure 3), which were active only at concentrations greater than or equal to $1000 \mu \mathrm{g} / \mathrm{mL}$. Thus, the native EPS (EPS-OC) seemed to be the most active compared to other exopolysaccharide extracts (EPS-2C and EPS-5C). 


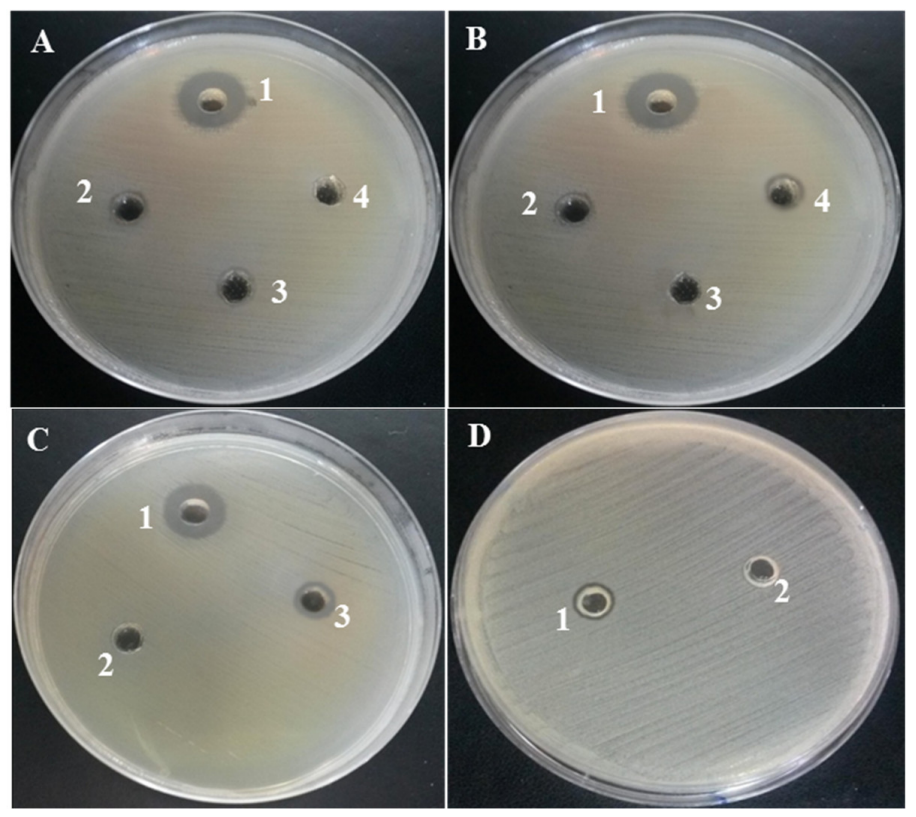

Figure 3. Zones of inhibition of the different bacterial strains affected by the exopolysaccharide extracts. (A): Activity against E. coli, 1: EPS-0C, 2: EPS-2C, 3: EPS-5C, 4: water, (B): Activity against S. aureus, 1: EPS-0C, 2: EPS -5C, 3: water, 4: EPS-2C, (C): Activity against Salmonella, 1: EPS-0C, 2: water, 3: EPS-2C, (D): Activity against SMR, 1: EPS-0C, 2: water.

\subsubsection{Inhibition of Biofilm Formation by Candida Albicans ATCC 10231}

P. marinum EPS extracts were tested for their ability to inhibit Candida albicans biofilm formation by the 96-well plate crystal violet test. The three fractions (EPS-0C, EPS-2C and EPS-5C) were revealed to be active against the formation of Candida albicans biofilm (Figure 4) without affecting the planktonic growth of this yeast, as no mortality had been observed previously (Table 3).

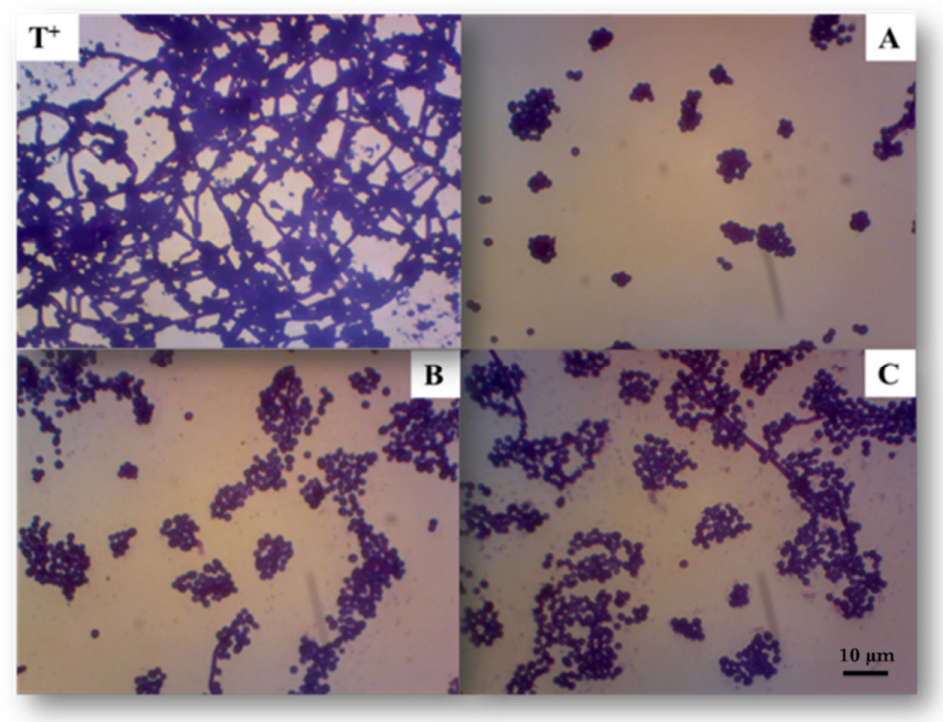

Figure 4. Representative reverse microscopy images of the biofilm formed by C. albicans ATCC 10231 in absence (positive control: $\mathrm{T}^{+}$) or in the presence of exopolysaccharides at active concentrations. (A): EPS-0C at $31.3 \mu \mathrm{g} / \mathrm{mL}$; (B): EPS-2C at $125 \mu \mathrm{g} / \mathrm{mL}$ and (C): EPS-5C at $250 \mu \mathrm{g} / \mathrm{mL}$. The assay was performed on a 96 -well plate for $24 \mathrm{~h}$ at $37^{\circ} \mathrm{C}$ and the adherent biofilm cells were stained by crystal-violet. 
Based on this observation, active EPS do not appear to target cell viability; they instead represent compounds whose mechanism of action would be the inhibition of the virulent form of $C$. albicans, in particular the transition from the yeast form to the mycelial form. As shown on Figure 5, the native polymer EPS-OC was the most active compared to other fractions (EPS-2C and EPS-5C). In fact, it has shown an inhibition of $90 \pm 1 \%$ at a concentration equal to $31.3 \mu \mathrm{g} / \mathrm{mL}$, not significantly different from the efficiency of farnesol, used as a positive control, which inhibits $91 \%$ of C. albicans biofilm formation at $31.3 \mu \mathrm{g} / \mathrm{mL}$ concentration. However, EPS-2C inhibited the formation of biofilm by up to $78 \pm 2 \%$ at $125 \mu \mathrm{g} / \mathrm{mL}$ and EPS-5C had an activity of $83 \pm 3 \%$ at a concentration of $250 \mu \mathrm{g} / \mathrm{mL}$.

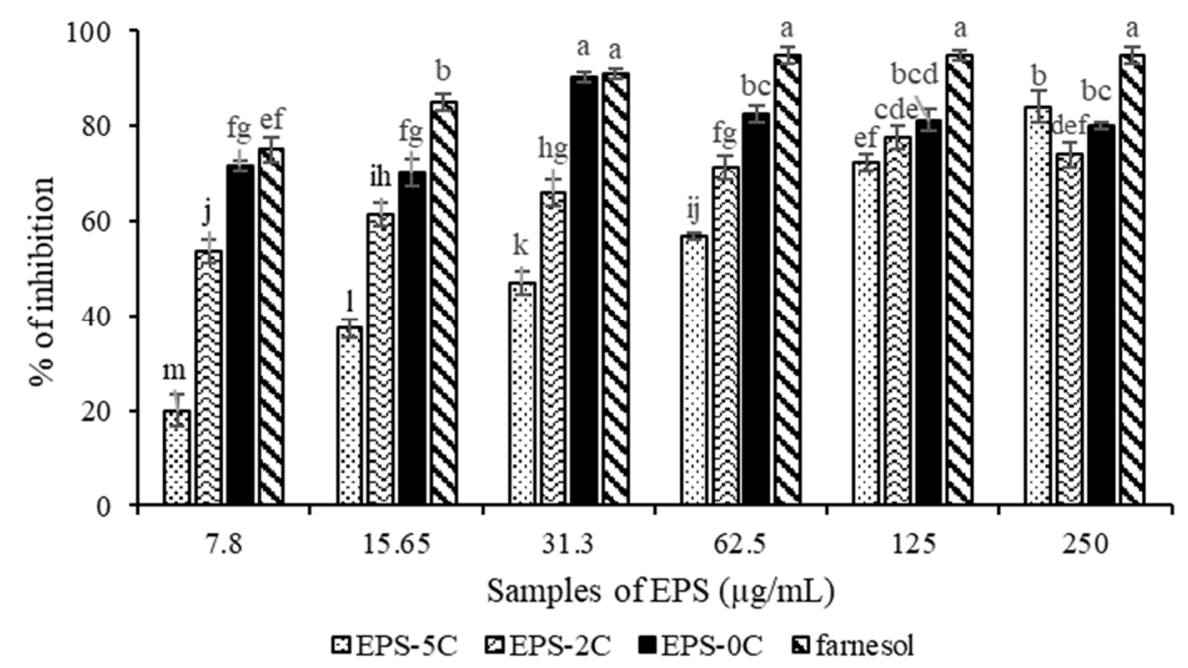

Figure 5. Percentage of inhibition of Candida albicans biofilm formation by different molar masses EPS from P. marinum (EPS-0C, EPS-2C and EPS-5C) and at different concentrations between 7.8 and $250 \mu \mathrm{g} / \mathrm{mL}$. Farnesol was used as a positive control. Results were expressed as mean \pm standard deviations of triplicate determinations. Different lowercase letters stand for significantly different values (Duncan multiple range test, $p<0.05$ ).

\subsubsection{T1 Mammary Carcinoma Cells Sensitivity towards EPS Samples}

The results of the in vitro test of the different EPS fractions on a murine breast carcinoma 4T1 cell lines have shown an antiproliferative activity on cancer cells mainly for EPS-2C and EPS-5C fractions (Figure 6). Indeed, the EPS-0C extract at the concentration of $2 \mathrm{mg} / \mathrm{mL}$ showed no significant inhibition of cancer cells with a percentage of viability equal to $85 \pm 0.8 \%$, which was found to not be significantly different from the viability obtained at the lower concentration $(>90 \%)$. This result highlights the fact that the native EPS has no activity on carcinoma cells proliferation. In contrast, the antiproliferative activity was improved with the EPS-2C and EPS-5C exopolysaccharides having lower molar masses, as they were found to reduce the cell viability by $51 \pm 0.75 \%$ and $45 \pm 0.82 \%$, respectively at a concentration of $2 \mathrm{mg} / \mathrm{mL}$. As shown on Figure 6, EPS-2C and EPS-5C inhibited the proliferation of cancer cells in a concentration-dependent manner. In fact, the more the concentration (from 0.0625 to $2 \mathrm{mg} / \mathrm{mL}$ ) increased, the more the antiproliferative activity of cancer cells increased, but with no statistically different behavior between the 2 samples.

Cytotoxicity of EPS samples was assayed on mammalian cell line Vero. Viability of cells was evaluated for each sample and at different concentrations (up to $5 \mathrm{mg} / \mathrm{mL}$ ). Results showed that on the whole range of concentrations tested (between 9.75 to $5000 \mu \mathrm{g} / \mathrm{mL}$ ), and for the 3 extracts (EPS-0C, EPS-2C and EPS-5C), no significant difference in viability was observed, and that it was almost 100\% in all cases. As the CC50 (The 50\% cytotoxic concentration, defined as the sample concentration able to reduce the cell viability by $50 \%$ when compared to an untreated control) of the samples were evaluated to be $>5 \mathrm{mg} / \mathrm{mL}$, 
and that no cytotoxic effect was observed for these samples in the range of concentrations used for the XTT test, the decrease in cell viability of carcinoma cells (about 50\%) observed for $2 \mathrm{mg} / \mathrm{mL}$ concentrations could not be attributed to a cytotoxicity of the extracts and thus confirmed the antiproliferative effect.

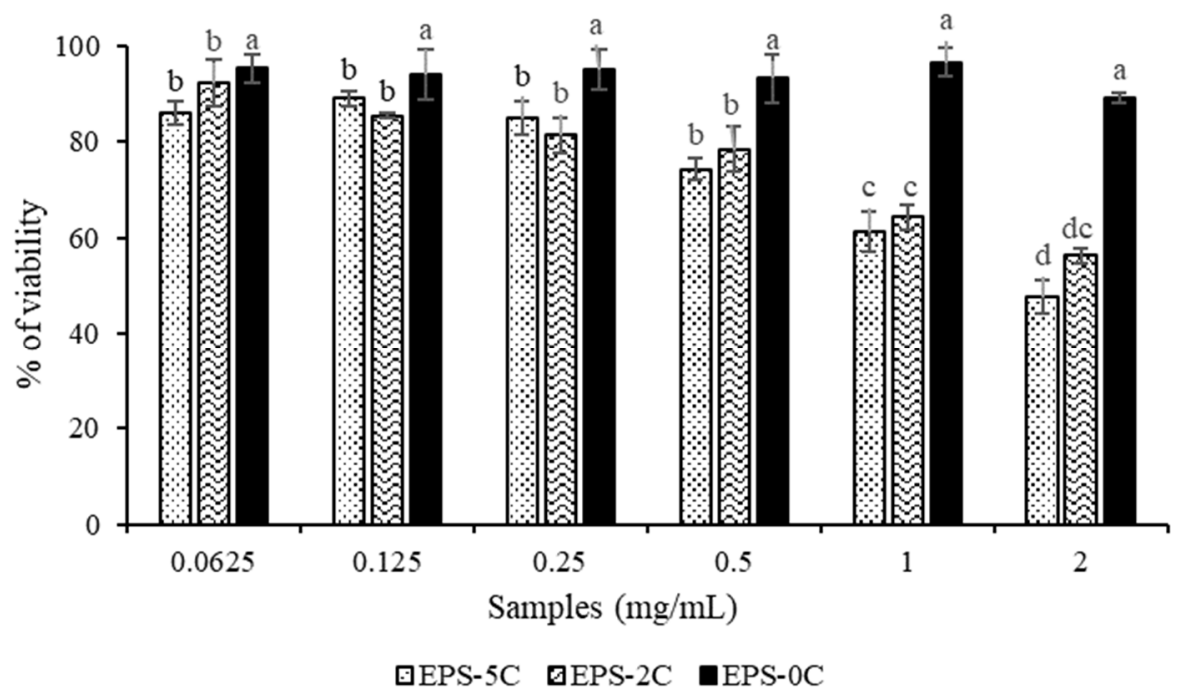

Figure 6. Percentage of viability of murine mammary carcinoma cells $4 \mathrm{~T} 1$ under the action of EPS samples from P. marinum (EPS-0C, EPS-2C and EPS-5C), at concentrations between 0.0625 and $2 \mathrm{mg} / \mathrm{mL}$. Results were expressed as mean \pm standard deviations of triplicate determinations. Different lowercase letters stand for significantly different values (Duncan multiple range test, $p<0.05)$.

\section{Discussion}

EPS from red microalgae showed several biological activities [28-33] that were generally linked to their molecular weight, rheological behavior $[23,34]$ and their content in sulfate groups and uronic acids. In our study, we evaluated the global and monosaccharide composition, the FTIR footprint, the amount of uronic acids and sulfate groups and the molecular masses of our samples. These results are in accordance with other studies on P. marinum EPS [6,7]. EPS from microalgae are complex molecules (much more complex than polysaccharides from other sources), making their complete characterization really challenging. Only a few numbers of EPS coming from microalgae have been studied for glycosidic linkages and none of these studies have led to a complete and defined structure [2]. The cause of this poor knowledge of EPS structures is linked to the fact that these heteropolymers often contains 5 to 10 different monosaccharides, numerous non-sugar substituents such as sulfate, methyl, acetyl and/or pyruvyl groups, and they apparently lack a repeating unit. In a drug development approach, it is mandatory to have fully characterized molecules at the molecular level, including resolution of the glycosidic linkages. However, methods that are classically applied successfully to polysaccharides from other sources (NMR, MALDI-TOF, GC-MS/EI) actually fail to resolve the structure of EPS from microalgae [2]. Even if the elucidation of this complete structure is still lacking, we intended to highlight a potential relationship between structure, physico-chemical properties and activities.

Many researchers have reported that minor changes in molar masses, or viscosity can have positive effects on antitumor activity. In this study, we demonstrate that EPS-2C and EPS-5C show an anti-proliferative activity against breast cancer cells at a high concentration of $2 \mathrm{mg} / \mathrm{mL}$ (Figure 6). This activity could be attributed to their lower molar masses and therefore to their low viscosity, thereby increasing their absorption and permeation ability. By further decreasing the molar masses of EPS from P. marinum, it could then be expected to increase this anti-proliferative effect. In 2009, Gardeva et al. [34] reported the anti-tumor 
activity of Porphyridum cruentum exopolysaccharide. They discovered that this sulfated polymer strongly inhibited proliferation of Graffi myeloid tumors in vitro and in vivo. These authors hypothesized that the anticancer activity of the exopolysaccharide extracted from Porphyridium cruentum could be associated with its immunostimulatory action as well as its direct cytotoxic properties. In 2012 [35], the anti-tumor and immunomodulatory activities of $P$. cruentum exopolysaccharides of different molar masses were evaluated on the mouse model carrying the S180 tumor in vivo and on the activation of peritoneal macrophages in vitro. The degraded EPSs showed a net immunomodulation dependent on their molar masses as well as the administered concentration. The smallest fragment of $6.53 \mathrm{kDa}$ had the strongest immuno-reinforcing activity, which was in agreement with the results obtained in our study. Other studies have confirmed that many types of polysaccharides, such as lentinan, Spirulina maxima polysaccharide and Chondrus ocellatus $\lambda$ carrageenan, exhibited significant antitumor activity for low molar masses samples [36-38]. In general, the antitumor effects of polysaccharides involve several mechanisms such as modification of the biochemical character of the cell membrane, induction of differentiation and apoptosis of tumor cells and regulation of cell signaling pathways. Nevertheless, immunomodulation is generally considered to be the most important mechanism [39]. It will then be interesting to test lower molar masses samples for antitumoral activity, and to evaluate the immunomodulatory effect to go further in the comprehension of the mechanism.

Bacteria are very common microorganisms in the pathogenic state. The best known and encountered bacteria in the medical sector is Staphylococcus aureus which is involved in nosocomial infections [40], but which can also be responsible for food poisoning just like Escherichia coli and Salmonella [41,42]. However, some bacteria also have developed an increased resistance to clinical antibiotics like methicillin, rendering it ineffective [43]. Candida albicans is the most common microorganism among fungal infections, causing high mortality and morbidity especially in immunocompromised patients [44]. The formation of the biofilm represents the virulent form of the pathogen contributing to the pathogenesis of candidiasis. The formation of the Candida albicans biofilm is favored by the passage from the unicellular yeast form (blastopore) to the mycelial form (hyphe and pseudohyphe) [45,46], with the ability to strongly adhere to biological surfaces or inert surfaces of medical devices [47]. Biofilm formation leads to high levels of resistance to most conventional antifungal agents, mainly fluconazole and amphotericin B, which have several limitations in terms of efficacy, toxicity, drug interaction and high cost. Thus, the search for alternative strategies and the development of new and more effective antifungal and antibacterial agents is necessary for better therapeutic management. For these reasons, EPS fractions from P. marinum were also tested for their antimicrobial and antibiofilm activities. It was found that the native EPS as well as the depolymerized EPS (EPS-2C and EPS-5C) provided an antibacterial and antibiofilm activity with different efficiency levels (Table 3, Figure 5). Our EPS can thus be considered as a powerful inhibitor of bacterial multiplication compared to other exopolysaccharides extracted from other microalgae. De Jesus Raposo et al. [48] indicated that the EPS produced by Porphyridium cruentum exhibited antibacterial activity against Gram (+) (S. aureus) and Gram (-) bacteria (E. coli and S. Enteritidis). Indeed at $1 \%$ $(w / v)$, it clearly inhibited $S$. Enteritidis, reducing CFU to $19 \%$. However, the concentration used in the present study was much lower. The most active fraction was the native EPS at low concentrations that were not showing high viscosity $(31.3 \mu \mathrm{g} / \mathrm{mL}$ for the inhibition of the biofilm of Candida albicans 110231, $62.5 \mu \mathrm{g} / \mathrm{mL}$ for anti-Escherichia coli ATCC 25922 multiplication and $125 \mu \mathrm{g} / \mathrm{mL}$ for anti-Salmonella Enteritidis ATCC 13076 and antiStaphylococcus aureus ATCC 29213 growth). Very few polysaccharides from microalgae were described as negatively impacting biofilm formation. The only available study has shown that the cell-bound polysaccharide from Navicula phyllepta specifically inhibited biofilm formation from the bacteria Flavobacterium sp., while it stimulated biofilm development by Roseobacter, and Shewanella genera [49]. In comparison with the literature, the efficiency of EPS-0C to inhibit biofilm formation by C. albicans observed in this study was greater 
$(>90 \%)$, and this for much lower applied doses $(31.3 \mu \mathrm{g} / \mathrm{mL})$. However, the active dose of EPS-2C and $5 \mathrm{C}$ was found to be greater than for EPS-0C, showing that decreasing the molar mass has a negative impact on their efficiency.

The native EPS was also active against Staphylococcus aureus methicillin resistant at a concentration equal to $1000 \mu \mathrm{g} / \mathrm{mL}$ (Table 3) showing a significant viscosity (Figure 2A). Therefore, in addition to the functional groups (sulfate and uronic acids, see Table 2) present on EPS-0C, the role of viscosity cannot be excluded from its inhibiting properties on the multiplication of SMR. The rheological behavior of the EPS-2C and EPS-5C fractions was always the same regardless of the applied concentration $(2500 \mu \mathrm{g} / \mathrm{mL}, 1000 \mu \mathrm{g} / \mathrm{mL}$ or $125 \mu \mathrm{g} / \mathrm{mL})$ (Figure 2B,C). At these concentrations, these samples have a low viscosity and exhibit a Newtonian behavior. Therefore, the biological activity of these EPSs against bacterial strains and the inhibition of Candida albicans biofilm formation could be attributed to their chemical composition, probably primarily to the sulfate and uronic acids groups, as several studies have relied on biological activity with the presence of sulfate groups $[33,48,50,51]$. Nevertheless, the sulfation degree may not be the only parameter to be considered to explain the biological activity of polysaccharides. Their position and therefore their "accessibility" can improve or not improve the biological activity of the EPS, as demonstrated by [6]. Moreover, several different mechanisms may exist, as non-sulfated polysaccharides (such as chitosan) have exhibited significant efficiency as an antibacterial and antibiofilm agent. For example, Costa et al. [52] have shown that the highest percentage inhibition of biofilm formation by C. albicans ( $66.94 \%$ ) was obtained for high molar masses chitosan at $0.5 \mathrm{mg} / \mathrm{mL}$ and the lowest inhibition percentage (37.97\%) was obtained for the low molar masses at $0.75 \mathrm{mg} / \mathrm{mL}$, which was in agreement with our results. Cobrado et al. [53] also showed that low molar masses chitosan $(107 \mathrm{kDa})$ was able to reduce C. albicans biofilm formation up to $41 \%$ at a $2.5 \mathrm{mg} / \mathrm{mL}$ concentration. For antibacterial activities, results are sometimes controversial, with depending on studies, greater efficiency on Gram (+) bacteria $[54,55]$ or on Gram $(-)$ ones [56,57]. In fact, the antimicrobial activities of chitosan would be greatly dependent on its physical characteristics, most notably weight average molar masses (Mw) and degree of deacetylation (DD) (for a review, see [58]). Therefore, the antimicrobial mechanisms and structure-function relationships of polysaccharides remain to be elucidated.

\section{Materials and Methods}

\subsection{Extraction of Exopolysaccharides}

The exopolysaccharide was recovered from a culture of red microalga Porphyridium marinum, obtained from Culture Collection of Algae and Protozoa (http:/ / www.ccap.ac. $\mathrm{uk} /$ ). Cultivation was conducted in $2 \mathrm{~L}$ Erlenmeyer flask, containing $1 \mathrm{~L}$ of Pm medium [7], under continuous light at $150 \mu$ mole photons $/ \mathrm{m}^{2} / \mathrm{s}$, stirring at $110 \mathrm{rpm}$ and at a temperature of $20^{\circ} \mathrm{C}$. The medium was inoculated with $100 \mathrm{~mL}$ of a subculture. As previously described [7], synthesis and accumulation of EPS occurred after nitrogen deprivation and entry in a stationary phase. Culture was stopped after 30 days, centrifugated $(10,000 \times g$, $30 \mathrm{~min}, 20^{\circ} \mathrm{C}$ ), and the supernatant was desalted and concentrated using a tangential filtration cassette (Vivaflow 200, Sartorius, Göttingen, Germany) having a cutoff threshold of $100 \mathrm{kDa}$ [7]. Finally, the resulting EPS solution was lyophilized before storage at room temperature.

\subsection{Preparation of Different-MW Exopolysaccharides}

The exopolysaccharide of P. marinum was treated using a High Pressure Homogenizer (HPH, 2.7 kbars, TS HAIVA, Constant Systems LTD, Daventry, UK) to obtain polysaccharide fractions of different molar masses. A polysaccharide stock solution was prepared at a concentration of $2 \mathrm{~g} / \mathrm{L}$. Up to five successive cycles were used to obtain 3 samples which were subsequently recovered and lyophilized. The corresponding degraded samples are labeled as follows, according to the number of cycles in the HPH: 
- EPS-OC for the undegraded sample,

- $\quad$ EPS-2C for the polysaccharide after two cycles,

- $\quad$ EPS-5C for the polysaccharide after five cycles.

\subsection{Exopolysaccharides Characterization}

\subsubsection{Total Sugars, Neutral Sugars, Uronic Acids, Sulfate and Proteins Content}

Total sugar content of samples was evaluated by the resorcinol method using glucose as standard [59]. Uronic acids and neutral sugar contents of EPS extracts were assayed with meta-hydroxyldiphenyl (m-HDP) and resorcinol as described by, respectively, [60] and [59] using glucose and glucuronic acid as standards. In these assays, glycosidic linkages are broken during high temperature sulfuric acid treatment and dehydration of sugar units leads to furfural compounds formation. These latter interact by condensation with phenolic compounds (resorcinol or m-HDP depending on the assay), giving colored compounds that can be measured respectively at 450 or $520 \mathrm{~nm}$. Briefly, for the m-HDP assay, $200 \mu \mathrm{L}$ of sample are mixed with $1 \mathrm{~mL}$ of a $0.12 \mathrm{M}$ borax $\left(\mathrm{Na}_{2} \mathrm{~B}_{4} \mathrm{O}_{7}, 10 \mathrm{H}_{2} \mathrm{O}\right)$ prepared in $96 \%(w / v)$ sulfuric acid. After a $1 \mathrm{~h}$ incubation at $90^{\circ} \mathrm{C}, 200 \mu \mathrm{L}$ of $\mathrm{m}-\mathrm{HDP}$ solution are added and absorbance measured at $520 \mathrm{~nm}$. The m-HDP solution is prepared just before assay by diluting $102 \mu \mathrm{L}$ of m-HDP stock solution (100 mg of m-HDP solubilized in $1 \mathrm{~mL}$ DMSO, kept at $\left.4{ }^{\circ} \mathrm{C}\right)$ with $5 \mathrm{~mL}$ of $80 \%(w / v)$ sulfuric acid. The results were expressed in $\mathrm{mg} / \mathrm{g}$ of D-glucuronic acid equivalent (GlcAEq). For resorcinol assay, $200 \mu \mathrm{L}$ of sample are mixed with $200 \mu \mathrm{L}$ of a $6 \mathrm{~g} / \mathrm{L}$ resorcinol solution and $1 \mathrm{~mL}$ of $80 \%(w / v)$ sulfuric acid. After $30 \mathrm{~min}$ at $90^{\circ} \mathrm{C}$, followed by $30 \mathrm{~min}$ at room temperature, $1.4 \mathrm{~mL}$ of water are added and absorbance at $450 \mathrm{~nm}$ is measured. The results directly expressed in $\mathrm{mg} / \mathrm{g}$ of D-glucose equivalent (GlcEq) correspond to the total sugars amount. As the uronic acids interfere with the assay, a glucuronic acid standard curve was performed following the same procedure, and the corrective formula described by [61] was applied, in order to access the neutral sugars amount.

Sulfur content was determined by the turbidimetric method [62] using $\mathrm{K}_{2} \mathrm{SO}_{4}$ as a standard. Results were expressed in $\mathrm{mg} / \mathrm{g}$ of $\mathrm{SO}_{4}$ equivalent. Briefly, $120 \mathrm{mg}$ of samples were hydrolyzed with $3 \mathrm{~mL}$ of $2 \mathrm{M}$ chlorhydric acid for $2 \mathrm{~h}$ at $100^{\circ} \mathrm{C}$. After centrifugation $(10,000 \times \mathrm{g}, 30 \mathrm{~min}), 1 \mathrm{~mL}$ of supernatant is added to $9 \mathrm{~mL}$ of milliQ water, $1 \mathrm{~mL}$ of $0.5 \mathrm{M}$ $\mathrm{HCl}$, and $0.5 \mathrm{~mL}$ of $\mathrm{BaCl}_{2}$ /gelatin reagent $(150 \mathrm{mg}$ of gelatin dissolved in $50 \mathrm{~mL}$ of water at $70{ }^{\circ} \mathrm{C}$, kept $16 \mathrm{~h}$ at $4{ }^{\circ} \mathrm{C}$, and finally mixed with $0.5 \mathrm{~g}$ of $\mathrm{BaCl}_{2}$ ). After 30 min incubation at room temperature, sulfate groups released during the hydrolysis of polysaccharides form a precipitate of barium sulfate, which can be detected at $550 \mathrm{~nm}$. Protein content was evaluated by the Lowry method [63] using bovine serum albumin (BSA) as a standard.

\subsubsection{Monosaccharide Composition of EPS}

The identification and quantification of the constitutive monosaccharides of $P$. marinum EPS was conducted by high performance anion exchange chromatography (HPAEC) on an ICS 3000 (Dionex, Sunnyvale, CA, USA). Exopolysaccharides were hydrolyzed with $2 \mathrm{M}$ TFA at $120{ }^{\circ} \mathrm{C}$ for $1 \mathrm{~h} 30 \mathrm{~min}$, neutralized with $35 \%$ ammonia and then centrifuged at $14,000 \times g$ for $15 \mathrm{~min}$. The recovered supernatant was filtered at $0.22 \mu \mathrm{m}$ before injection. The elution was carried out with a pre-column and a CarboPac PA1 column $(4 \times 50 \mathrm{~mm}$ and $4 \times 250 \mathrm{~mm}$, respectively) whose stationary phase is an anion exchange resin. Samples were eluted isocratically with $18 \mathrm{mM} \mathrm{NaOH}$ for $25 \mathrm{~min}$, followed by a linear gradient between 0 and $0.5 \mathrm{M}$ sodium acetate in $200 \mathrm{mM} \mathrm{NaOH}$ for $20 \mathrm{~min}$ to elute acidic monosaccharides. Run was followed by $15 \mathrm{~min}$ washing with $200 \mathrm{mM} \mathrm{NaOH}$. The eluent flow rate was kept constant at $1 \mathrm{~mL} / \mathrm{min}$. A range of external standards (Fucose, Arabinose, Galactose, Glucose, Rhamnose, Xylose, Mannose, Fructose, Ribose, Galactosamine, Glucosamine, N-AcetylGlucosamine, N-AcetylGalactosamine, Galacturonic acid and Glucuronic acid) with concentrations ranging from 0.001 to $0.01 \mathrm{~g} / \mathrm{L}$, and then the addition of internal standards in the samples enabled qualitative and quantitative analysis of the composition of polysaccharides. 


\subsubsection{Molar Masses Determination}

Molar masses and polydispersity index of EPS were analyzed by a size exclusion chromatography coupled to a multiangle laser light scattering detector, a viscometric detector and a differential refractive index detector (SEC/MALLS/Visco/DRI). The polysaccharide solutions were prepared at $0.5 \mathrm{mg} / \mathrm{mL}$ (dilute regime) in the chromatographic eluent (i.e., $\mathrm{LiNO}_{3}$ at $0.1 \mathrm{M}$, filtered on $0.1 \mu \mathrm{m}$ ) under soft magnetic agitation at $60{ }^{\circ} \mathrm{C}$ during $4 \mathrm{~h}$ and then filtrated on a $0.45 \mu \mathrm{m}$ filter unit (regenerated cellulose). An automatic sample injector (SIL 20A, Shimadzu, Kyoto, Japan) equipped with a $500 \mu \mathrm{L}$ injection loop was used for injection. The solvent was driven by a pump (LC 10Ai, Shimadzu, Kyoto, Japan) at a flow rate of $0.5 \mathrm{~mL} / \mathrm{min}$. The sample was first drawn into a pre-column (Shodex OHPAK SB-G) before being directed to two standard steric exclusion columns (Shodex OHPAK SB 804 and $806 \mathrm{HQ}$ ). At the outlet of the column, the compounds were quantified by a differential refractometer (DRI 10A, Shimadzu, Kyoto, Japan), a multi-angle laser light scattering detector (Dawn ${ }^{\circledR}$ heleos, Wyatt technology Corp., Santa Barbara, CA, USA) equipped with a $\mathrm{K} 5$ cell of $50 \mu \mathrm{L}$, a red source (Ga-As $690 \mathrm{~nm}$ ) of $5 \mathrm{~mW}, 18$ measurement diodes and a viscosity detector (Viscostar 2, Wyatt Technology Corp., Goleta, CA, USA). The data obtained was processed with the Astra 6.1.1 software which provided the weight and number average molar masses $\left(\mathrm{M}_{\mathrm{n}}\right.$ and $\mathrm{M}_{\mathrm{w}}$, respectively) and also the gyration (Rg) radius

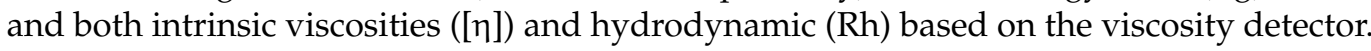

\subsubsection{Infrared Spectrometry Footprint (FTIR)}

Infrared measurements were made using a VERTEX 70 (Bruker, Billerica, MA, USA) spectrometer. The samples were analyzed on an ATR A225 diamond module. IR spectra (50 scans) were obtained at room temperature (referenced against air) over the $500-4000 \mathrm{~cm}^{-1}$ range. The spectra were analyzed with the OPUS 7.2 software.

\subsubsection{Shear Flow Behavior of EPS Samples}

The shear flow behavior of samples (viscosity measurements as function of shear rate) was determined using an AR-G2 rheometer (TA Instruments Ltd., Hertfordshire, UK). Measurements were conducted using a steel cone-plate $\left(40 \mathrm{~mm}\right.$ radius, $2^{\circ}$, gap $\left.50 \mu \mathrm{m}\right)$ geometry. The temperature was set at $30^{\circ} \mathrm{C}$, with a circulating bath or a Peltier system depending on geometry. The viscosity measurements were made over a shear rate range of 1 to $10^{3} \mathrm{~s}^{-1}$.

\subsection{Biological Activities}

\subsubsection{Antibacterial Activity}

Four bacterial strains: Staphylococcus aureus ATCC 29213, methicillin-resistant Staphylococcus aureus (SMR), Escherichia coli ATCC 25922 and Salmonella Enteritidis ATCC 13076, were used as indicator strains for the determination of the antibacterial activity. Exopolysaccharides samples were tested for antibacterial activity by using the well diffusion method and the minimum inhibitory concentration (MIC) using the microdilution method on sterile 96-well plate [64]. Briefly, on Petri dishes containing solid Luria broth (LB) medium previously inoculated with the bacterial inoculum, $6 \mathrm{~mm}$ wells were dug in the medium and then sealed with a thin layer of liquefied soft agar to limit the diffusion of the sample under the solid medium. Samples with $50 \mu \mathrm{L}$ of exopolysaccharides were placed in each well. Sterile distilled water was used as a negative control. The diameters of the inhibition zones were measured after $18 \mathrm{~h}$ of incubation at $30^{\circ} \mathrm{C}$.

To determine the MIC, bacterial strains were grown in $\mathrm{LB}$ medium at $30^{\circ} \mathrm{C} .10^{5} \mathrm{CFU} / \mathrm{mL}$ of each bacterial suspension were incubated for $24 \mathrm{~h}$ at $30^{\circ} \mathrm{C}$ in the presence of the test sample at concentrations ranging from 7.81 to $1000 \mu \mathrm{g} / \mathrm{mL}$. Wells containing the bacterial strain alone were used as a positive control, while wells containing only the culture medium were considered as a negative control. MIC values were determined for the lowest concentration of the extract, showing complete inhibition of bacterial cell growth. 


\subsubsection{Anti-Candida Albicans Activity}

Detection of antifungal activity against Candida albicans 10231 was performed using the microdilution method on a 96-well plate, as previously described by Grieco et al. [65]. Briefly, a culture of $\mathrm{C}$. albicans $\left(30{ }^{\circ} \mathrm{C}\right.$ in WB medium) is diluted in the same growth medium to reach $10^{5} \mathrm{UFC} / \mathrm{mL}$ and the suspension is introduced in each well, with different concentrations of samples between 7.81 and $1000 \mu \mathrm{g} / \mathrm{mL}$ and the plate is incubated $24 \mathrm{~h}$ at $37^{\circ} \mathrm{C}$. Two controls were included. The negative control corresponds to the growth medium, and the positive control contains $C$. albicans in the growth medium. MIC values were determined as the lowest concentration of the extract showing complete inhibition of Candida cell growth.

\subsubsection{Inhibition of Biofilm Formation}

Biofilm quantification was performed using the crystal violet staining assay on a 96-well polystyrene plate, as demonstrated by Jin et al. [66]. Indeed, a suspension of Candida albicans with a final concentration of $10^{5} \mathrm{CFU} / \mathrm{mL}$ was prepared in the RPMI 1640 culture medium (R8758, Sigma-Aldrich, St. Quentin Fallavier Cedex, France). Fifty microliters of $C$. albicans inoculum was distributed into each well of the microplate in the presence of different exopolysaccharides samples, with concentrations ranging from 7.81 to $1000 \mu \mathrm{g} / \mathrm{mL}$ to have a final volume of $100 \mu \mathrm{L}$. The plate was then incubated at $37^{\circ} \mathrm{C}$ for $24 \mathrm{~h}$. After incubation, crystal violet staining was performed to demonstrate the inhibitory effect of biofilm formation. Briefly, the culture medium was removed and each well was washed twice with PBS buffer $(\mathrm{pH}=7.4 ; 0.1 \mathrm{M})$. For biofilm fixation, $100 \mu \mathrm{L}$ of $99 \%$ methanol was added. The biofilm was then stained with $0.05 \%$ crystal violet for $15 \mathrm{~min}$ at room temperature. The excess was removed by two washes with ultra pure water. Purple coloration appeared after the addition of $100 \mu \mathrm{L}$ of $33 \%$ acetic acid and was detected at $630 \mathrm{~nm}$. The percentage of biofilm inhibition was determined by the equation below:

$$
\% \text { inhibition }=\left[100-\left(\left(\mathrm{A}_{\text {Sample }}-\mathrm{A}_{\text {blank }}\right) /\left(\mathrm{A}_{\text {Control }}-\mathrm{A}_{\text {blank }}\right)\right)\right] \times 100
$$

with $\mathrm{A}_{\mathrm{Blank}}$ and $\mathrm{A}_{\mathrm{Control}}$ corresponding to the absorbance of RPMI medium and untreated biofilm at $630 \mathrm{~nm}$, respectively.

\subsubsection{Cytotoxicity Evaluation}

Cytotoxicity EPS samples were tested on mammalian cell line Vero using MTT method according to Medjeldi et al. [67], measuring absorbance at $540 \mathrm{~nm}$. The percentage of cytotoxic effect was calculated using the following equation:

$$
\left[\left(\mathrm{A}_{\text {Control }}-\mathrm{A}_{\text {Sample }}\right) /\left(\mathrm{A}_{\text {Control }}\right)\right] \times 100 .
$$

The 50\% cytotoxic concentration (CC50), defined as the sample concentration able to reduce the cell viability by $50 \%$ when compared to an untreated control, was determined by linear regression analysis from a dose-response curve.

\subsubsection{Antiproliferative Effect of Different $\mathrm{M}_{\mathrm{W}}$-EPS on Breast Cancer Cells}

The exopolysaccharides samples were tested for their ability to inhibit the proliferation of the $4 \mathrm{~T} 1$ murin breast carcinoma cells. The antiproliferative activity was determined by the XTT test as described in the Cell Proliferation Kit II (Sigma, 11465015001 Roche, St. Quentin Fallavier, France).

The results were expressed as a percentage of viability via the following formula:

$$
\% \text { Viability }=\left(\mathrm{A}_{\text {test }} / \mathrm{A}_{\text {control }}\right) \times 100
$$

$\mathrm{A}_{\text {Control }}$ : Absorbance of untreated cells at $450 \mathrm{~nm}$. 


\subsection{Statistical Analyses}

Data were collected from three independent experiments assayed in triplicate and expressed as the mean \pm standard deviation (SD). The statistical significance was analyzed by one-way ANOVA with STATISTICA. 5 software. The post-hoc test of Duncan multiple range was used to perform comparisons. Results were considered as statistically significant with a $p<0.05$.

\section{Conclusions}

The present study demonstrated the biological activity of different molar masses exopolysaccharides from Porphyridium marinum. Interestingly, our findings clearly revealed the potentiality of native exopolysaccharide EPS-OC to inhibit the proliferation of Gram $(+)$ and Gram (-) bacteria, as well as the formation of biofilm of Candida albicans at low concentration. However, the low molar masses exopolysaccharides EPS-2C and EPS-5C were found to be more effective for antiproliferative activity against breast cancer cells. Depending on the biological activity tested, this study also disclosed that these biological activities could be due to their molar masses, their viscosity as well as their composition (probably their content in sulfate and uronic acids). Thus, this study provides strong arguments to consider exopolysaccharides from Porphyridium marinum as a natural source of antibacterial, antibiofilm and anticancer products that are useful in pharmaceutical formulations and food industries as a natural preservative. Nevertheless, this study constitutes a first step to evaluate the potential of EPS from P. marinum in a drug development approach.

Supplementary Materials: The following are available online at https:/ / www.mdpi.com/1660-339 7/19/2/66/s1, Figure S1: HPAEC chromatograms of native (a: EPS-0C) and depolymerized EPS (b: EPS-2C, c: EPS-5C).

Author Contributions: Conceptualization: N.G., I.F. and C.L.; Investigation: N.G., I.K., F.E., C.G. and C.R.; Supervision: C.P., S.A., O.T., I.F. and C.L.; Validation: I.F. and C.L.; Writing-original draft: N.G. and C.L.; Writing—review \& editing: I.K., C.R., L.P., I.F., N.G. and C.L. All authors have read and agreed to the published version of the manuscript.

Funding: This research received no external funding.

Institutional Review Board Statement: Not applicable.

Informed Consent Statement: Not applicable.

Data Availability Statement: Data is contained within the article or Supplementary Materials.

Conflicts of Interest: The authors declare no conflict of interest.

\section{References}

1. Gargouch, N.; Karkouch, I.; Elleuch, J.; Elkahoui, S.; Michaud, P.; Abdelkafi, S.; Laroche, C.; Fendri, I. Enhanced B-phycoerythrin production by the red microalga Porphyridium marinum: A powerful agent in industrial applications. Int. J. Biol. Macromol. 2018, 120, 2106-2114. [CrossRef] [PubMed]

2. Delattre, C.; Pierre, G.; Laroche, C.; Michaud, P. Production, extraction and characterization of microalgal and cyanobacterial exopolysaccharides. Biotechnol. Adv. 2016, 34, 1159-1179. [CrossRef] [PubMed]

3. Li, S.; Ji, L.; Shi, Q.; Wu, H.; Fan, J. Advances in the production of bioactive substances from marine unicellular microalgae Porphyridium sp. Bioresour. Technol. 2019, 292, 122048. [CrossRef]

4. Gaignard, C.; Gargouch, N.; Dubessay, P.; Delattre, C.; Pierre, G.; Laroche, C.; Fendri, I.; Abdelkafi, S.; Michaud, P. New horizons in culture and valorization of red microalgae. Biotechnol. Adv. 2019, 37, 193-222. [CrossRef] [PubMed]

5. Geresh, S.; Arad, S.; Levy-Ontman, O.; Zhang, W. Isolation and characterization of poly- and oligosaccharides from the red microalga Porphyridium sp. Carbohydr. Res. 2009, 344, 343-349. [CrossRef]

6. Roussel, M.; Villay, A.; Delbac, F.; Michaud, P.; Laroche, C.; Roriz, D.; El Alaoui, H.; Diogon, M. Antimicrosporidian activity of sulphated polysaccharides from algae and their potential to control honeybee nosemosis. Carbohydr. Polym. 2015, 133, 213-220. [CrossRef]

7. Soanen, N.; Da Silva, E.; Gardarin, C.; Michaud, P.; Laroche, C. Improvement of exopolysaccharide production by Porphyridium marinum. Bioresour. Technol. 2016, 213, 231-238. [CrossRef]

8. Villay, A.; de Filippis, F.L.; Picton, L.; LeCerf, D.; Vial, C.; Michaud, P. Comparison of polysaccharide degradations by dynamic high-pressure homogenization. Food Hydrocoll. 2012, 27, 278-286. [CrossRef] 
9. Porto, B.C.; Cristianini, M. Effect of dynamic high pressure on emulsifying and encapsulant properties of cashew tree gum. Carbohydr. Polym. 2018, 186, 350-357. [CrossRef]

10. Fenoradosoa, T.A.; Laroche, C.; Delattre, C.; Dulong, V.; Lecerf, D.; Picton, L.; Michaud, P. Rheological behavior and nonenzymatic degradation of a sulphated galactan from Halymenia durvillei (Halymeniales, Rhodophyta). Appl. Biochem. Biotechnol. 2012, 167, 1303-1313. [CrossRef]

11. Geresh, S.; Adin, I.; Yarmolinsky, E.; Karpasas, M. Characterization of the extracellular polysaccharide of Porphyridium sp.: Molecular weight determination and rheological properties. Carbohyd. Polym. 2002, 50, 183-189. [CrossRef]

12. Bernaerts, T.M.M.; Kyomugasho, C.; Van Looveren, N.; Gheysen, L.; Foubert, I.; Hendrickx, M.E.; Van Loey, A.M. Molecular and rheological characterization of different cell wall fractions of Porphyridium cruentum. Carbohydr. Polym. 2018, 195, 542-550. [CrossRef] [PubMed]

13. Gaignard, C.; Macao, V.; Gardarin, C.; Rihouey, C.; Picton, L.; Michaud, P.; Laroche, C. The red microalga Flintiella sanguinaria as a new exopolysaccharide producer. J. Appl. Phycol. 2018, 30, 2803-2814. [CrossRef]

14. Capek, P.; Matulováa, M.; Combourieu, B. The extracellular proteoglycan produced by Rhodella grisea. Int. J. Biol. Macromol. 2008, 43, 390-393. [CrossRef] [PubMed]

15. Percival, E.; Foyle, A.R. The extracellular polysaccharides of Porphyridium cruentum and Porphyridium aerugineum. Carbohydr. Res. 1979, 72, 165-176. [CrossRef]

16. Medina-Cabrera, E.V.; Rühmann, B.; Schmid, J.; Sieber, V. Characterization and comparison of Porphyridium sordidum and Porphyridium purpureum concerning growth characteristics and polysaccharide production. Algal Res. 2020, 49, 101931. [CrossRef]

17. Monsoor, M.A.; Kalapathy, U.; Proctor, A. Determination of polygalacturonic acid content in pectin extracts by diffuse reflectance Fourier transform infrared spectroscopy. Food Chem. 2001, 74, 233-238. [CrossRef]

18. Gómez-Ordóñez, E.; Rupérez, P. FTIR-ATR spectroscopy as a tool for polysaccharide identification in edible brown and red seaweeds. Food Hydrocoll. 2011, 25, 1514-1520. [CrossRef]

19. Chopin, T.; Kerin, B.F.; Mazerolle, R. Phyccolloid chemistry as taxonomic indicator of phylogeny in the Gigartinales, Rhodophyceae: A review and current developments using fourrier transform infrared diffuse reflectance spectroscopy. Phycol. Res. 1999, 47, 167-188. [CrossRef]

20. Deng, J.; Shi, J.J.; Li, X.Z.; Liu, H.M. Soluble polysaccharides isolation and characterization from rabbit eye blueberry (Vaccinium ashei) fruits. Bioresources 2013, 8, 405-419.

21. Tomar, S.; Adaganti, S.Y. Production of ethanol using Calliandra shrub by hydrothermal pretreatment method. Int. J. Curr. Eng. Tech. 2013, 3, 1921-1924.

22. Li, G.Y.; Luo, Z.C.; Yuan, F.; Yu, X.B. Combined process of high-pressure homogenization and hydrothermal extraction for the extraction of fucoidan with good antioxidant properties from Nemacystus decipients. Food Bioprod. Process. 2017, 106, 35-42. [CrossRef]

23. Sun, L.; Wang, C.; Shi, Q.; Ma, C. Preparation of different molecular weight polysaccharides from Porphyridium cruentum and their antioxidant activities. Int. J. Biol. Macromol. 2009, 45, 42-47. [CrossRef] [PubMed]

24. Medina-Cabrera, E.V.; Gansbiller, M.; Rühmann, B.; Schmid, J.; Sieber, V. Rheological characterization of Porphyridium sordidum and Porphyridium purpureum exopolysaccharides. Carbohydr. Polym. 2021, 253, 117237. [CrossRef]

25. Geresh, S.; Arad, S.M. The extracellular polysaccharides of the red microalgae: Chemistry and rheology. Bioresour. Technol. 1991, 38, 195-201. [CrossRef]

26. Eteshola, E.; Karpasas, M.; Arad, S.M.; Gottlieb, M. Red microalga exopolysaccharides: 2. Study of the rheology, morphology and thermal gelation of aqueous preparations. Acta Polym. 1998, 49, 549-556. [CrossRef]

27. Balti, R.; Balc'h, R.L.; Brodu, N.; Gilbert, M.; Le Gouic, B.; Le Gall, S.; Sinquin, C.; Massé, A. Concentration and purification of Porphyridium cruentum exopolysaccharides by membrane filtration at various cross-flow velocities. Process Biochem. 2018, 74, 175-184. [CrossRef]

28. Matsui, S.M.; Muizzudin, N.; Arad, S.M.; Marenus, K. Sulfated polysaccharides from red microalgae anti-inflammatory properties in vitro and in vivo. Appl. Biochem. Biotechnol. 2003, 104, 13-22. [CrossRef]

29. Tannin-Spitz, T.; Bergman, M.; Van-Moppes, D.; Grossman, S.; Arad, S.M. Antioxidant activity of the polysaccharide of the red microalga Porphyridium sp. J. Appl. Phycol. 2005, 17, 215-222. [CrossRef]

30. Jiao, G.; Yu, G.; Zhang, J.; Ewart, H.S. Chemical structures and bioactivities of sulphated polysaccharides from marine algae. Mar. Drugs 2011, 9, 196-223. [CrossRef]

31. Guzmán-Murillo, M.A.; Ascencio, F. Anti-adhesive activity of sulphated exopolysaccharides of microalgae on attachment of the red sore disease-associated bacteria and Helicobacter pylori to tissue culture cells. Lett. Appl. Microbiol. 2000, 30, 473-478. [CrossRef] [PubMed]

32. Huheihel, M.; Ishanu, V.; Tal, J.; Arad, S.M. Activity of Porphyridium sp. polysaccharide against herpes simplex viruses in vitro and in vivo. J. Biochem. Biophys. Methods 2002, 48, 189-200. [CrossRef]

33. Arad, S.M.; Levy-Ontman, O. Red microalgal cell-wall polysaccharides: Biotechnological aspects. Curr. Opin. Biotech. 2010, 21, 358-364. [CrossRef] [PubMed]

34. Gardeva, E.; Toshkova, R.; Minkova, K.; Gigova, L. Cancer Protective Action of Polysaccharide, Derived from Red Microalga Porphyridium cruentum-A Biological Background. Biotechnol. Biotech. Equip. 2009, 23, 783-787. [CrossRef] 
35. Sun, L.; Wang, L.; Zhou, Y. Immunomodulation and antitumor activities of different molecular-weight polysaccharides from Porphyridium cruentum. Carbohydr. Polym. 2012, 87, 1206-1210. [CrossRef]

36. Chen, D.; Wu, X.Z.; Wen, Z.Y. Sulfated polysaccharides and immune response: Promoter or inhibitor? Panminerva Med. 2008, 177-183.

37. Zhou, G.F.; Sheng, W.X.; Yao, W.D.; Wang, C.H. Effect of low molecular $\lambda$-carrageenan from Chondrus ocellatus on antitumor H-22 activity of 5-Fu. Pharmacol. Res. 2006, 53, 129-134. [CrossRef]

38. Zhu, X.L.; Chen, A.F.; Lin, Z.B. Ganoderma lucidum polysaccharides enhance the function of immunological effector cells in immunosuppressed mice. J. Ethnopharmacol. 2007, 111, 219-226. [CrossRef]

39. Zhou, G.; Sun, Y.; Xin, H.; Zhang, Y.; Li, Z.; Xu, Z. In vivo antitumor and immunomodulation activities of different molecular weight lambda-carrageenans from Chondrus ocellatus. Pharmacol. Res. 2004, 50, 47-53. [CrossRef]

40. Valaperta, R.; Tejada, M.R.; Frigerio, M.; Moroni, A.; Ciulla, E.; Cioffi, S.; Capelli, P.; Costa, E. Staphylococcus aureus nosocomial infections: The role of a rapid and low-cost characterization for the establishment of a surveillance system. New Microbiol. 2010, 33, 223-232.

41. Zeaki, N.; Johler, S.; Skandamis, P.N.; Schelin, J. The Role of Regulatory Mechanisms and Environmental Parameters in Staphylococcal Food Poisoning and Resulting Challenges to Risk Assessment. Front. Microbiol. 2019, 10, 1307. [CrossRef] [PubMed]

42. Mostafa, A.A.; Al-Askar, A.A.; Almaary, K.S.; Dawoud, T.M.; Sholkamy, E.N.; Bakri, M.M. Antimicrobial activity of some plant extracts against bacterial strains causing food poisoning diseases. Saudi J. Biol. Sci. 2018, 25, 361-366. [CrossRef] [PubMed]

43. Tabbene, O.; Slimene, I.B.; Bouabdallah, F.; Mangoni, M.L.; Urdaci, M.; Limam, F. Production of Anti-Methicillin-Resistant Staphylococcus Activity from Bacillus subtilis sp. Strain B38 Newly Isolated from Soil. Appl. Biochem. Biotechnol. 2009, 157, 407-419. [CrossRef] [PubMed]

44. Lin, M.Y.; Yuan, Z.L.; Hu, D.D.; Hu, G.H.; Zhang, R.L.; Zhong, H.; Yan, L.; Jiang, Y.Y.; Su, J.; Wang, Y. Effect of loureirin A against Candida albicans biofilms. Chin. J. Nat. Med. 2019, 17, 616-623. [CrossRef]

45. Vale-Silva, L.A.; Buchta, V.; Valentova, E. Effect of sub-inhibitory concentration of some established and experimental antifungal compounds on the germ tube formation in Candida albicans. Folia Microbiol. 2007, 52, 39-43. [CrossRef] [PubMed]

46. Ariyachet, C.; Solis, N.V.; Liu, Y.; Prasadarao, N.V.; Filler, S.G.; McBride, A.E. SR-Like RNA-binding protein Slr1 affects Candida albicans filamentation and virulence. Infect. Immun. 2013, 81, 267-1276. [CrossRef]

47. Borghi, E.; Morace, G.; Borgo, F.; Rajendran, R.; Sherry, L.; Nile, C.; Ramage, G. New strategic insights into managing fungal biofilms. Front. Microbiol. 2015, 6, 1077. [CrossRef]

48. de Jesus Raposo, M.F.; de Morais, A.M.; de Morais, R.M. Influence of sulphate on the composition and antibacterial and antiviral properties of the exopolysaccharide from Porphyridium cruentum. Life Sci. 2014, 101, 56-63. [CrossRef]

49. Doghri, I.; Lavaud, J.; Dufour, A.; Bazire, A.; Lanneluc, I.; Sablé, S. Cell-bound exopolysaccharides from an axenic culture of the intertidal mudflat Navicula phyllepta diatom affect biofilm formation by benthic bacteria. J. Appl. Phycol. 2017, 29, 165-177. [CrossRef]

50. Vijayabaskar, P.; Vaseela, N.; Thirumaran, G. Potential antibacterial and antioxidant properties of a sulfated polysaccharide from the brown marine algae Sargassum swartzii. Chin. J. Nat. Med. 2012, 10, 421-428. [CrossRef]

51. Amorim, R.; Rodrigues, J.; Holanda, M.; Quinderé, A.; Paula, R.; Melo, V.M.M.; Benevides, N.M.B. Antimicrobial effect of a crude sulfated polysaccharide from the red seaweed Gracilaria ornate. Braz. Arch. Biol. Technol. 2012, 55, 171-181. [CrossRef]

52. Costa, E.; Silva, S.; Tavaria, F.; Pintado, M. Antimicrobial and Antibiofilm Activity of Chitosan on the Oral Pathogen Candida albicans. Pathogens 2014, 3, 908-919. [CrossRef] [PubMed]

53. Cobrado, L.; Silva-Dias, A.; Azevedo, M.M.; Pina-Vaz, C.; Rodrigues, A.G. In vivo antibiofilm effect of cerium, chitosan and hamamelitannin against usual agents of catheter-related bloodstream infections. J. Antimicrob. Chemother. 2013, 68, 126-130. [CrossRef] [PubMed]

54. No, H.K.; Park, N.Y.; Lee, S.H.; Meyers, S.P. Antibacterial activity of chitosans and chitosan oligomers with different molecular weights. Int. J. Food Microbiol. 2002, 74, 65-72. [CrossRef]

55. Silva, L.P.; Britto, D.; Seleghim, M.H.R.; Assis, O.B.G. In vitro activity of water-soluble quaternary chitosan chloride salt against. E coli. World J. Microbiol. Biotechnol. 2010, 26, 2089-2092. [CrossRef]

56. Laroche, C.; Delattre, C.; Mati-Baouche, N.; Salah, R.; Ursu, A.V.; Moulti-Mati, F.; Michaud, P.; Pierre, G. Bioactivity of Chitosan and Its Derivatives. Curr. Org. Chem. 2018, 22, 641-667. [CrossRef]

57. Rabea, E.I.; Badawy, M.E.T.; Stevens, C.V.; Smagghe, G.; Steurbaut, W. Chitosan as antimicrobial agent: Applications and mode of action. Biomacromolecules 2003, 4, 1457-1465. [CrossRef]

58. Liu, X.F.; Guan, Y.L.; Yang, D.Z.; Li, Z.; Yao, K.D. Antibacterial action of chitosan and carboxymethylated chitosan. J. Appl. Polym. Sci. 2001, 79, 1324-1335.

59. Monsigny, M.; Petit, C.; Roche, A.C. Colorimetric determination of neutral sugars by a resorcinol sulfuric acid micromethod Anal. Biochem. 1988, 175, 525-530. [CrossRef]

60. Blumenkrantz, N.; Asboe-Hansen, G. New method for quantitative determination of uronic acids. Anal. Biochem. 1973, 54, 484-489. [CrossRef]

61. Montreuil, J.; Spick, G.; Chosson, A.; Segard, E.; Scheppler, N. Methods of study of the structure of glycoproteins. J. Pharm. Belg. 1963, 18, 529-546. [PubMed] 
62. Dodgson, K.S.; Price, R.G. A note on the determination of the ester sulphate content of sulphated polysaccharides. Biochem. J. 1962, 84, 106-110. [CrossRef] [PubMed]

63. Lowry, O.H.; Rosenbrough, N.J.; Farr, A.L.; Randall, R.J. Protein measurement with the folin phenol reagent. J. Biol. Chem. 1951, 193, 265-269. [CrossRef]

64. Azaiez, S.; Ben Slimene, I.; Karkouch, I.; Essid, R.; Jallouli, S.; Djebali, N.; Elkahoui, S.; Limam, F.; Tabbene, O. Biological control of the soft rot bacterium Pectobacterium carotovorum by Bacillus amyloliquefaciens strain Ar10 producing glycolipid-like compounds. Microbiol. Res. 2018, 217, 23-33. [CrossRef]

65. Grieco, P.; Carotenuto, A.; Auriemma, L.; Limatola, A.; Di Maro, S.; Merlino, F.; Mangoni, M.L.; Luca, V.; Di Grazia, A.; Campiglia, P.; et al. Novel $\alpha$-MSH peptide analogues with broad spectrum antimicrobial activity. PLoS ONE 2013, 8, e61614. [CrossRef]

66. Jin, Y.; Yip, H.K.; Samaranayake, Y.H.; Yau, J.Y.; Samaranayake, L.P. Biofilm-forming ability of Candida albicans is unlikely to contribute to high levels of oral yeast carriage in cases of human immunodeficiency virus infection. J. Clin. Microbiol. 2003, 41, 2961-2967. [CrossRef]

67. Medjeldi, S.; Bouslama, L.; Benabdallah, A.; Essid, R.; Haou, S.; Elkahoui, S. Biological activities, and phytocompounds of northwest Algeria Ajuga iva (L) extracts: Partial identification of the antibacterial fraction. Microb. Pathog. 2018, 121, 173-178. [CrossRef] 